\title{
INSURANCE ASSESSMENTS IN INANGAHUA
}

\author{
D. I. D. Bird*
}

The Inangahua earthquake was the first occasion on which New Zealand adjusters have been faced with a large volume of claims for earthquake damage in a number of different localities. Consequently most of the adjusters working on the earthquake claims were treading unbroken ground, and their experience should be of assistance in the handling of any similar disaster in the future.

\section{Determination of insured losses}

Factors to be taken into account in this connection are:

(i) Basis of Insurance. The Earthquake \& War Damage Act makes it clear that the compulsory insurance for earthquake damage is on the basis of indemnity value only. The obligation of the Commission is merely to make good (by payment or reinstatement or repair, at the option of the Commission) the loss or damage by earthquake. Clearly, in assessing earthquake claims, we must have regard for the pre-earthquake condition of the damaged property, and allow only for the cost of restoring property to its previous condition.

(ii) Extent of Damage. In the epicentral area it was not difficult to distinguish the earthquake damage from pre-existing damage. There was however, a problem with considerable arrears of maintenance on many buildings, with the consequence that the allowance of the full cost of repairs placed a claimant in a better position than before the earthquake, Consequently, in most cases the Commission was entitled to insist on a contribution by the claimant for betterment.

(iii) Basis of Costing. Without the advantage of a local Builders' Association, tradesmen assessors working in Reefton, all of whom came from other localities, had first to ascertain the local ruling prices and costs. Allowances then had to be made for travelling time and cartage for itinerant tradesmen or firms from other areas, and the possibility that many accounts would contain quite a large element of overtime. Discussions with local repairers, and others who had moved into the locality to assist with reinstatement, were held, both under the auspices of the Civil Defence Organisation, and in private negotiations, and proved very helpful in removing misunderstandings.

(iv) Costs of Reinstatement. Factors influencing building repair costs were the isolation of the area necessitating increased costs for travelling time and cartage, the inadequacy of the (normal) repair resources in the area necessitating the employment of firms from outside, the need to make generous allowances for contingencies both foreseeable and unforeseeable, and the impossibility of exacting adequate contributions from property owners for betterment without creating a political furore. The same sorts of considerations applied in respect of claims for home appliances, furniture, etc.

(v) Indemnity Valuations. Since the insurance is on the basis of indemnity valuation, the pre-earthquake indemnity value of each building had to be taken into account in deciding the amount of the loss. Many buildings were sub-standard and poorly maintained, and property values generally were depressed, with the consequence that in many cases indemnity values were less than the amounts of insurance, and considerably less than the reinstatement costs. The state of the property market was such that professional valuers had the greatest difficulty in determining fair values. 
(vi) Collation of Insurances. The amount of the insured loss depends of course on the amount of insurance on the particular property. In too many cases this information was too difficult to obtain. Most property owners knew the name of their insurers, and applications were made almost immediately for full particulars of the insurances. Nonetheless, adequate information concerning some insurances was still not available two months after the earthquake.

(vii) Excluded losses. Certain types of property are expressly excluded from the application of the Earthquake \& War Damage Act, and adjusters must not take damage to such property into account in determining the amount of the loss. Probably the exclusions which created most difficulty were the ones referring to water reticulation pipes, electric supply poles and lines, retaining walls and fences, and septic tanks.

\section{Adjustment of claims}

Having determined a fair value of the loss, the adjuster still has to negotiate a settlement which will be satisfactory to the insurer and the claimant. Factors to be taken into consideration include:

(viii) Option to Reinstate. The Commission has the option to reinstate damaged properties, but this cannot really be exercised generally in a locality in which there is such a wide discrepancy between indemnity value and replacement value. Consequently, the reinstatement of earthquake damaged buildings must be delayed while legal and financial problems are resolved. In this sort of situation authority to reinstate must be given by the property owner to the repair contractor, and generally this authority will not be forthcoming until the property owner knows the probable cost of reinstatement, the amount he can expect from his insurances, and the source of any finance to bridge the gap. In the Inangahua area, valuable assistance to all property owners was made available by the Government through the use of Ministry of Works personnel to assess repair costs, prepare specifications, obtain tenders and supervise the work of reinstatement.

(ix) Use of Counsellor or Social Worker. In the epicentral area in particular, where people are both frightened and shocked, suffering loss of livelihood, sometimes suffering separation from their families, and exhausted from long hours of work and worry, the availability of a trained counsellor or social worker to work with the adjuster is essential. This function was performed in Inangahua by the Anglican Vicar of Reefton, Rev. Michael Smart. His assistance was invaluable. Not only did he know the locality and the people, but he had the confidence of the people and the adjusters, and acted as a mediator between the parties.

(x) Interviewing Committee. A scheme was devised for the interviewing of claimants from the epicentral area by a committee of three members, comprising Rev. Smart as chairman, and an insurance adjuster and a building supervisor (see prior paper by M. Smart). In many cases a number of return visits was required to ensure that the claimants, while still shocked and distressed, were fully aware of their rights and of the various alternative courses of action open to them. 